\title{
Response to post-axitinib treatment in patients with metastatic renal cell carcinoma
}

\author{
Namita Chittoria ${ }^{1,4^{*}}$, Housam Haddad', Paul Elson ${ }^{1}$, Nizar M. Tannir ${ }^{2}$, Laura S. Wood', Robert Dreicer ${ }^{3}$, \\ Jorge A. Garcia', Brian I. Rini ${ }^{1}$ and Eric Jonasch ${ }^{2}$
}

\begin{abstract}
Background: Axitinib is a potent inhibitor of the vascular endothelial growth factor (VEGF) receptor family with clinical activity in patients with metastatic renal cell carcinoma (mRCC). Given this biochemical potency, the clinical activity of subsequent treatment with targeted therapies in patients progressing on axitinib is of interest.

Methods: Patients with advanced renal cell carcinoma of any pathologic subtype treated with at least one cycle (four weeks) of axitinib followed by at least one subsequent targeted therapy were investigated in a retrospective analysis. Patient characteristics, duration of treatment and clinical outcomes were analyzed for axitinib and each subsequent line of therapy by Response Evaluation Criteria in Solid Tumors (RECIST).

Results: Twenty-five mRCC patients who received at least one approved targeted agent following axitinib were identified. Eight percent of patients achieved a partial response (one patient each to sunitinib and pazopanib) and $42 \%$ had a best response of stable disease to the first therapy after axitinib. The estimated median duration of therapy was 4.4 months (range, 0.2-27.5+). Twelve patients received a second post-axitinib targeted therapy. Six out of 11 evaluable patients ( $55 \%$ ) had a best response of SD. The estimated median duration of treatment was 4.8 months (range, 0.7-19.1+).
\end{abstract}

Conclusion: Objective responses and stable disease is observed to post-axitinib targeted therapies and prospective studies are needed for validating role of predictive biomarkers.

Keywords: Renal cell carcinoma, Axitinib, Sunitinib, VEGF inhibitors, mTOR inhibitors, Predictive biomarkers

\section{Background}

Renal cell carcinoma (RCC) is a biologically heterogeneous disease with distinct genetic and metabolic defects [1]. Over the past decade, recognition that von HippelLindau $(V H L)$ gene mutations cause overexpression of vascular endothelial growth factor (VEGF) and increased tumor angiogenesis has led to development of multiple agents targeting this protein and its receptor.

Currently approved therapies for treatment of patients with mRCC include bevacizumab (plus interferon alfa), a humanized monoclonal antibody that inhibits the VEGF

\footnotetext{
* Correspondence: namita.chittoria@yahoo.com

${ }^{1}$ Cleveland Clinic Taussig Cancer Center, 9500 Euclid Ave., Cleveland, OH, USA

${ }^{4}$ Veteran Affairs Medical Center, 800 Irving Avenue, Syracuse, NY 13210, USA Full list of author information is available at the end of the article
}

ligand, and the multi-targeted receptor tyrosine kinase inhibitors, sunitinib, sorafenib, pazopanib and axitinib (VEGFr- TKIs) [2-7]. Each agent has a slightly different affinity for the VEGF and platelet derived growth factor (PDGF) receptors, as well as for other receptor tyrosine kinases [8]. Mammalian target of rapamycin (mTOR) inhibitors, which include everolimus and temsirolimus $[9,10]$ are also approved for treatment of $\mathrm{mRCC}$, and do not appear to have a direct effect on VEGF or its receptors.

The most recently Food and Drug Administration (FDA) approved agent for $\mathrm{mRCC}$ is axitinib, a second-generation, indazole derived molecule that binds selectively to the adenosine triphosphate (ATP)-binding intracellular domain of VEGFR-1, 2, and 3 at sub-nanomolar concentrations. The AXIS trial that led to the approval of axitinib was a 
phase 3, randomized controlled study comparing two VEGFr TKIs, axitinib and sorafenib, in patients whose disease progressed on initial systemic therapy [7]. Patients in each treatment arm had received first-line treatment with sunitinib (54\%), cytokines (35\%), bevacizumab ( $8 \%)$, or temsirolimus (3\%). In the overall population, patients treated with axitinib experienced a significantly longer median progression free survival (PFS) than patients treated with sorafenib (6.7 vs. 4.7 months; $P<0.0001$ ). Secondary endpoints included overall response rate (ORR), overall survival (OS), and safety and tolerability. ORR was $19.4 \%(95 \% \mathrm{Cl}$ 15.4-23.9 \%) versus $9.4 \%$ (95\% CI 6.6-12.9\%) for axitinib and sorafenib, respectively. In the sub-group of sunitinib-refractory patients, median PFS was 4.8 months for patients treated with second-line axitinib and 3.4 months for patients treated with second-line sorafenib $(P=0.0107)$. In the subgroup of cytokine-refractory patients, median PFS was 12.1 months for patients treated with second-line axitinib and 6.5months for patients treated with second-line sorafenib $(P<0.0001)$ [11]. The longer median PFS values observed in cytokine-refractory patients relative to sunitinib-refractory patients points to partial cross-resistance with sequential VEGF-targeted therapy [11]. This suggests that targeting of the same pathway with sequential VEGFr-TKI therapy may follow a law of diminishing returns due to unknown mechanisms of increasing resistance [12].

Knowing that axitinib is the most biochemically potent of the approved VEGFr inhibitors, and that there is possibility of cross-resistance with sequential VEGF-targeting therapy, the response to therapy after progressing on axitinib is of clinical interest.

A retrospective review of patients from the Cleveland Clinic Taussig Cancer Center (CCF) and MD Anderson Cancer Center (MDACC) was thus undertaken to characterize and evaluate the response to subsequent systemic therapy in patients who had progressed on axitinib.

\section{Methods}

\section{Study design and patient characteristics}

Patients from CCF or MDACC were identified through prospectively maintained databases and included in the study, which was approved by Cleveland Clinic and UT MD Anderson institutional review board. The initial criteria for case identification included a diagnosis of metastatic RCC of any pathologic subtype and treatment with at least one cycle (four weeks) of axitinib. Eightyone patients treated with axitinib between November 2003 and August 2010 were initially identified; 25 patients (17 (68 \%) from CCF and 8 (32\%) from MDACC) received at least one approved targeted agent following axitinib and were included in this analysis. The remaining patients were excluded due to $\leq 4$ weeks on axitinib $(n=3)$, ongoing axitinib therapy $(n=16)$, lack of subsequent systemic therapy $(n=13)$, lost to follow up $(n=11)$, receiving non targeted or investigational agents post-axitinib $(n=11)$ or were not evaluable $(n=2)$. All patients were enrolled in axitinib clinical trials given that axitinib therapy pre-dated FDA approval.

Data collection was performed via retrospective review of each patient's medical record and recorded on a spreadsheet standardized between the two centers. Patient characteristics, duration of treatment and clinical outcomes were analyzed for axitinib and each subsequent line of therapy. Objective response was defined according to RECIST version 1.0. All imaging studies were done at MDACC or CCF and response was evaluated by treating physicians at each institute. There was no centralized review of the radiological findings. Response beyond the second subsequent therapy was not evaluated because of lack of sufficient data.

\section{Statistical analyses}

Categorical data were summarized as frequency counts and percentages and measured data by medians and ranges. The Kaplan Meier method was used to summarize the duration of subsequent treatments since some patients were still receiving therapy at the time of analysis. The Wilcoxon signed rank test was used to compare treatment duration with axitinib to the duration on subsequent therapy in patients with complete data. Data analysis was conducted using SAS version 9.2 (SAS Inc., Cary NC)

\section{Results}

\section{Patient characteristics}

Twenty-five patients (17 (68\%) from CCF and 8 (32\%) from MDACC) received at least one approved targeted agent following axitinib and were included in this analysis. Patient characteristics at the start of axitinib were typical of an advanced RCC population and included $72 \%$ male, median age 59 (range, 44-78); $96 \%$ clear cell; $92 \%$ prior nephrectomy; $72 \%$ previously-treated. Patients had favorable (30\%) or intermediate (65\%) risk disease based on Heng criteria [13]. The overall RECIST-defined objective response rate to axitinib was $56 \%$ (one complete and 13 partial response) and the median duration of treatment with axitinib was 11.2 months (range, 1.1-90) (Table 1).

\section{Response to first subsequent therapy post axitinib}

Following axitinib therapy, patients were treated with VEGF receptor inhibitors $(n=18)$ or mTOR inhibitors $(n=7)$. Overall, $8 \%$ of patients achieved a partial response (one patient each to sunitinib and pazopanib) and $42 \%$ had a best response of stable disease (nine patients to VEGF receptor inhibitors and four patients to mTOR inhibitors). The 
Table 1 Patient characteristics and clinical outcomes to axitinib

\begin{tabular}{|c|c|}
\hline Characteristic & $\mathrm{N}(\%)$ \\
\hline \multicolumn{2}{|l|}{ Gender } \\
\hline Male & $18(72 \%)$ \\
\hline Female & $7(28 \%)$ \\
\hline \multicolumn{2}{|l|}{ Age at Start of Axitinib (years) ${ }^{a}$} \\
\hline Median (range) & $59(44-78)$ \\
\hline \multicolumn{2}{|l|}{ Histology } \\
\hline Clear cell & $24(96 \%)$ \\
\hline Unclassified & $1(4 \%)$ \\
\hline \multicolumn{2}{|l|}{ Prior Nephrectomy } \\
\hline No & $2(8 \%)$ \\
\hline Yes & $23(92 \%)$ \\
\hline \multicolumn{2}{|l|}{ Prior Systemic Treatment } \\
\hline No & $7(28 \%)$ \\
\hline Yes & $18(72 \%)$ \\
\hline IFN and/or IL-2 & $11(44 \%)$ \\
\hline Sorafenib & $9(36 \%)$ \\
\hline Sunitinib & $6(24 \%)$ \\
\hline Temsirolimus & $1(4 \%)$ \\
\hline Bevacizumab & $1(3 \%)$ \\
\hline Other ${ }^{b}$ & $4(16 \%)$ \\
\hline \multicolumn{2}{|c|}{ Interval from Dx of Mets to Axitiniba } \\
\hline Median in months (range) & $20.1(0.2-49.9)$ \\
\hline \multicolumn{2}{|l|}{ ECOG PS } \\
\hline 0 & $7(28 \%)$ \\
\hline 1 & $18(72 \%)$ \\
\hline \multicolumn{2}{|l|}{ Heng Risk Group ${ }^{c}$} \\
\hline Favorable & 7 (30 \%) \\
\hline Intermediate & $15(65 \%)$ \\
\hline Unfavorable & $1(4 \%)$ \\
\hline \multicolumn{2}{|l|}{ Sites of Metastatic Disease } \\
\hline Lung & $20(80 \%)$ \\
\hline Lymph nodes & $13(52 \%)$ \\
\hline Bone & $6(24 \%)$ \\
\hline Liver & $5(20 \%)$ \\
\hline Adrenal & $5(20 \%)$ \\
\hline Pancreas & $4(16 \%)$ \\
\hline Brain & $2(8 \%)$ \\
\hline Other $^{d}$ & $12(48 \%)$ \\
\hline \multicolumn{2}{|l|}{ Best Response to axitinib } \\
\hline$C R$ & $1(4 \%)$ \\
\hline PR & $13(52 \%)$ \\
\hline SD & $10(40 \%)$ \\
\hline PD & $1(4 \%)$ \\
\hline
\end{tabular}

Table 1 Patient characteristics and clinical outcomes to axitinib (Continued)

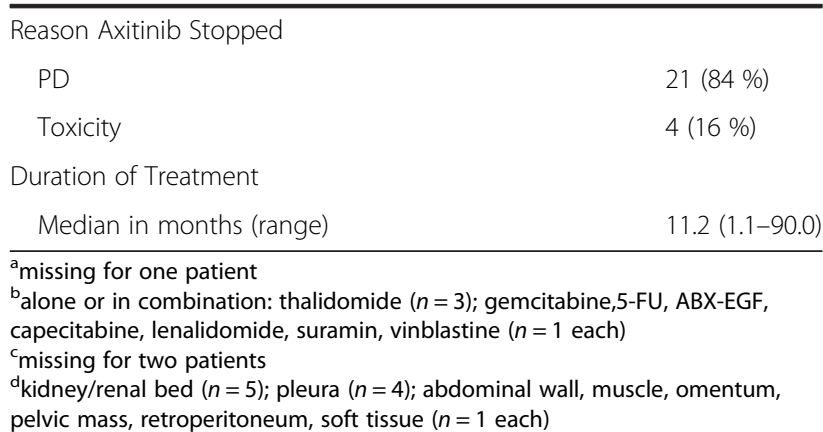

estimated median duration of subsequent therapy was 4.4 months (range, 0.2-27.5+) (Table 2).

The response to first subsequent therapy was evaluated in the subgroup of patients who had received axitinib as second-line or later therapy $(72 \%, 18 / 25)$ and in patients who had received no therapy prior to axitinib (28 \%, 7/25). Ten patients (55\%) had a best response of stable disease in the group of patients who had received axitinib as second-line or later therapy as compared to three $(42 \%)$ in the latter group. One patient achieved partial response in both groups (Table 3).

\section{Response to second subsequent therapy post axitinib}

Eleven of twelve patients who received a second postaxitinib targeted therapy were treated with VEGF receptor inhibitors $(n=3)$ or mTOR inhibitors $(n=8)$. No partial responses were observed. However, six of 11 evaluable patients (55\%) had a best response of SD to mTOR inhibitors. The estimated median duration of treatment was 4.8 months (range, $0.7-19.1+$ ).

Patient response to subsequent therapy was generally less favorable than the response to axitinib. This was true also for four patients who discontinued axitinib due to toxicity and not due to progressive disease. Among 13 evaluable patients who achieved a CR or PR on axitinib, only $2(15 \%)$ achieved a PR on their next systemic therapy, 7 (54 \%) had a best response of stable disease, and 4 (31\%) progressed.

Further, Fig. 1 delineates two populations The majority of the 14 patients who had a prolonged response to axitinib had brief responses ( $<3$ months) to subsequent therapies; however seven patients $(28 \%)$ remained on their first post-axitinib therapy longer than on axitinib. Despite this, the overall duration of axitinib treatment was longer as compared to subsequent therapy (median 11.2 versus 4.4 months, $p=0.04$ ). All of these seven patients had clear cell RCC without sarcomatoid features and six of these seven patients received sunitinib or pazopanib as first subsequent therapy and only one received temsirolimus. 
Table 2 Patient characteristics and clinical outcomes to post-axitinib systemic therapy

\begin{tabular}{|c|c|c|}
\hline Factor & $\begin{array}{l}\text { First post-axitinib therapy } \\
(n=25)\end{array}$ & $\begin{array}{l}\text { Second post-axitinib therapy } \\
(n=12)\end{array}$ \\
\hline $\begin{array}{l}\text { Interval from End of Axitinib Therapy to Start of Current Therapy } \\
\text { Median in weeks (range) }\end{array}$ & $2.0(0-41.7)^{\mathrm{a}}$ & $37.4(2.6-93.0)$ \\
\hline Treatment & N ( \%) & N ( \%) \\
\hline VEGF inhibitors & $18(72 \%)$ & $3(25 \%)$ \\
\hline Sunitinib & $8(32 \%)$ & $-0-$ \\
\hline Pazopanib & $6(24 \%)$ & $1(8 \%)$ \\
\hline Bevacizumab & $4(16 \%)$ & $2(17 \%)$ \\
\hline mTOR inhibitors & 7 (28 \%) & $8(67 \%)$ \\
\hline Everolimus & $5(20 \%)$ & $5(42 \%)$ \\
\hline Temsirolimus & $2(8 \%)$ & $3(25 \%)$ \\
\hline Other & $-0-$ & $1(8 \%)^{b}$ \\
\hline \multicolumn{3}{|l|}{ ECOG PS } \\
\hline 0 & $3(13 \%)$ & $2(17 \%)$ \\
\hline 1 & 19 (79 \%) & $9(75 \%)$ \\
\hline 2 & $2(8 \%)^{a}$ & $1(8 \%)$ \\
\hline \multicolumn{3}{|l|}{ Heng Risk Group } \\
\hline Favorable & $9(41 \%)$ & $3(30 \%)$ \\
\hline Intermediate & $12(55 \%)$ & $6(60 \%)$ \\
\hline Unfavorable & $1(5 \%)^{c}$ & $1(10 \%)^{d}$ \\
\hline \multicolumn{3}{|l|}{ Best Response } \\
\hline PD & $2(8 \%)$ & $-0-$ \\
\hline SD & $13(42 \%)$ & $6(55 \%)$ \\
\hline PD & 7 (28 \%) & $4(36 \%)$ \\
\hline Not evaluable & $3(12 \%)$ & $1(9 \%)^{a}$ \\
\hline \multicolumn{3}{|l|}{ Reason Treatment Stopped } \\
\hline PD/Death & 17 (68%) & $6(54 \%)$ \\
\hline Toxicity & $4(16 \%)$ & $2(18 \%)$ \\
\hline Treatment ongoing & $4(16 \%)$ & $3(27 \%)$ \\
\hline $\begin{array}{l}\text { Duration of Treatment (subsequent therapy) } \\
\text { Median in months (range) }\end{array}$ & $4.4(0.2-27.5+)^{a}$ & $4.8(0.7-19.1+)^{\mathrm{a}}$ \\
\hline
\end{tabular}

${ }^{\mathrm{a}}$ missing for one patient

${ }^{\mathrm{b}}$ MK2206

'missing for three patients

${ }^{d}$ missing for two patients

\section{Discussion}

The standard of care in metastatic RCC is the empiric and sequential use of systemic therapies, most of which target VEGF. Previous retrospective and prospective evidence points to lack of complete cross-resistance to sequential VEGF-targeting therapies [14, 15], although in general the clinical activity decreases with drugs given later in the sequence. The reasons for development of resistance to initial therapy and factors affecting response to subsequent therapy are not well understood at present. The present analysis demonstrates that clinical responses (objective partial responses and stable disease) are possible if VEGF receptor inhibitors are given after axitinib, although in general the activity of subsequent therapy is less than that observed with axitinib.

It has been hypothesized that residual VEGF signaling after VEGF-targeted therapy could account for the activity of VEGF-targeted agents in this setting. Given the increased biochemical potency of axitinib, it was hypothesized that therapy (specifically VEGF-targeted therapy) after axitinib treatment may not result in clinical benefit. Our retrospective data suggests that clinical effect is seen in patients with metastatic RCC who receive systemic therapy after axitinib, not only as second but also as third line. Two thirds of our patients had received systemic therapy prior to axitinib and we 
Table 3 Prior treatments and clinical outcomes to axitinib and first subsequent therapy

\begin{tabular}{|c|c|c|c|c|c|c|c|}
\hline $\begin{array}{l}\text { Patient } \\
\text { ID }\end{array}$ & Therapies prior to Axitinib & $\begin{array}{l}\text { Duration of } \\
\text { axitinib treatment } \\
\text { (mon) }\end{array}$ & $\begin{array}{l}\text { Best } \\
\text { response to } \\
\text { Axitinib }\end{array}$ & $\begin{array}{l}\text { Reason for } \\
\text { discontinuation }\end{array}$ & $\begin{array}{l}\text { Interval from End of } \\
\text { Axitinib Therapy to } \\
\text { Start of Subsequent } \\
\text { Therapy (weeks) }\end{array}$ & $\begin{array}{l}\text { Subsequent } \\
\text { therapy } 1\end{array}$ & $\begin{array}{l}\text { Best } \\
\text { response }\end{array}$ \\
\hline 1 & IL-2 plus IFN & 18 & PR & PD & 28 & Sunitinib & PR \\
\hline 2 & IL-2 plus IFN & 90 & $P R$ & PD & 1 & Bevacizumab & SD \\
\hline 3 & IL-2 plus IFN & 24 & SD & PD & 41 & Sunitinib & $\begin{array}{l}\text { Not } \\
\text { evaluable }\end{array}$ \\
\hline 4 & IL-2 & 6 & $P R$ & PD & 0 & Pazopanib & PD \\
\hline 5 & IL-2 plus thalidomide, Sorafenib & 41 & PR & PD & 2 & Sunitinib & SD \\
\hline 6 & IL-2/Bevacizumab & 18 & SD & PD & 3 & Pazopanib & SD \\
\hline 7 & IL-2, sunitinib, IFN, sorafenib & 8 & SD & PD & 1 & Bevacizumab & PD \\
\hline 8 & IL-2 plus IFN, BAY 43-9006, Sorafenib & 31 & $P R$ & Toxicity, RPLS ${ }^{a}$ & 10 & Temserolimus & SD \\
\hline 9 & $\begin{array}{l}\text { IFN,vinblastin plus thalidomide,IL-2, } \\
\text { Gemcitabine plus Capecitabine, } \\
\text { Sorafenib }\end{array}$ & 53 & $P R$ & Toxicity, MI ${ }^{\mathrm{b}}$ & 7 & Pazopanib & SD \\
\hline 10 & IFN, Sunitinib, Sorafinib & 8 & SD & PD & 35 & Temserolimus & SD \\
\hline 11 & $\begin{array}{l}\text { IFN, IL-2/thalidomide, IL-2/IFN, sunitinib, } \\
\text { sorafenib }\end{array}$ & 11 & SD & PD & 2 & Bevacizumab & PD \\
\hline 12 & $\begin{array}{l}\text { ABX-EGF, CC-5013, 5FU/suramin, } \\
\text { Sorafinib }\end{array}$ & 4 & SD & PD & 5 & Sunitinib & SD \\
\hline 13 & Sunitinib & 1 & PD & PD & 0 & Everolimus & $\begin{array}{l}\text { Not } \\
\text { evaluable }\end{array}$ \\
\hline 14 & Sunitinb & 3 & SD & PD & 1 & Everolimus & PD \\
\hline 15 & Sunitinib & 3 & SD & PD & 0 & Everolimus & SD \\
\hline 16 & Sorafenib & 19 & PR & PD & 2 & Sunitinib & PD \\
\hline 17 & Sorafenibb & 41 & PR & PD & 2 & Sunitinib & SD \\
\hline 18 & Temsirolimus & 6 & $P R$ & Toxicity & 0 & Pazopanib & SD \\
\hline 19 & None & 29 & $P R$ & PD & 3 & Everolimus & SD \\
\hline 20 & None & 20 & $P R$ & PD & 2 & Everolimus & PD \\
\hline 21 & None & 2 & $C R$ & Toxicity & 0 & Pazopanib & $P R$ \\
\hline 22 & None & 4 & SD & PD & 32 & Sunitinib & SD \\
\hline 23 & None & 13 & $P R$ & PD & 2 & Bevacizumab & PD \\
\hline 24 & None & 6 & SD & PD & 2 & Pazopanib & SD \\
\hline 25 & None & 6 & $P R$ & PD & 3 & Sunitinib & $\begin{array}{l}\text { Not } \\
\text { evaluable }\end{array}$ \\
\hline
\end{tabular}

${ }^{\mathrm{a}}$ Reversible Posterior Leukoencephalopathy Syndrome

${ }^{\mathrm{b}}$ Myocardial Infarction

still observed objective responses on subsequent therapies, median duration of therapy was over four months and seven patients remained on first subsequent therapy longer than axitinib. This may be explained by the therapeutic effect of different target engagement by the various VEGF multikinase inhibitors [16, 17]. Our study also delineates two populations, one that responds better to axitinib and another to subsequent therapy. This variable response emphasizes possible role of molecular biomarkers in guiding individualized patient management and improving outcomes.
There are limitations to this analysis. This is a retrospective review of a small number of patients at two specialized institutions with inability to overcome selection bias. Individual treating physicians at each institute did the tumor assessment, thus limiting the reliability and consistency of the percent changes in tumor burden and the assessment of objective response.

Further prospective trials are evaluating second-line treatment with approved or investigational agents in patients with mRCC who were refractory to previous treatment with a targeted agent. Other trials are evaluating the optimal sequence of targeted agents in treatment- 


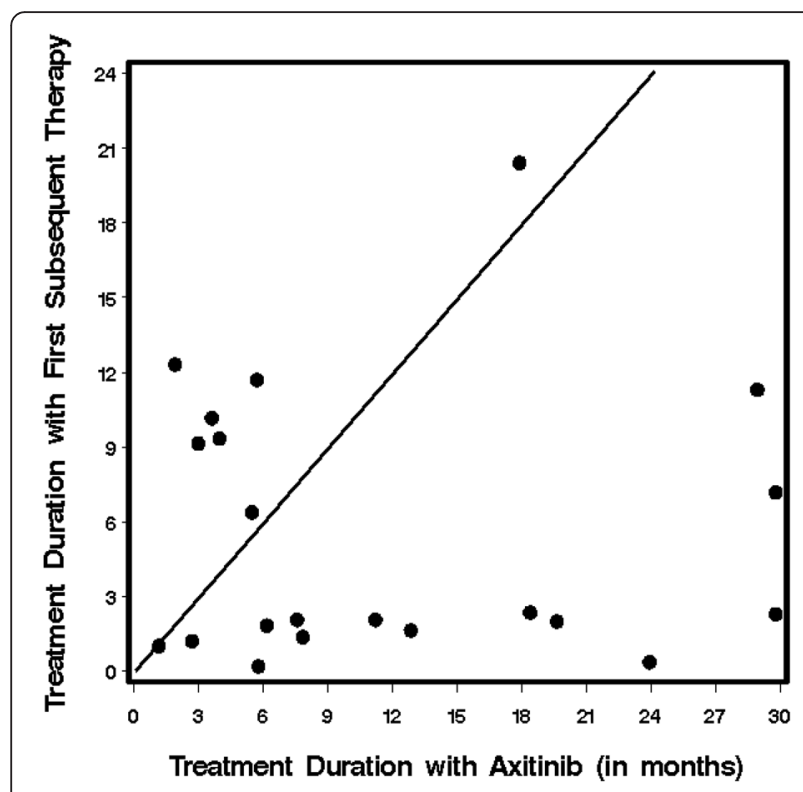

Fig. 1 Treatment Duration with Axitinib vs First Subsequent (Post - Axitinib) Systemic Therapy. Notes: Axitinib duration cropped at 30 months for two patients (actual durations were 53.1 and 90.0 months). Data points above the diagonal represent patients who remained on treatment longer with subsequent therapy than with axitinib; points below the diagonal represent the converse

naive patients with $\mathrm{mRCC}$. Results of these trials may give us some insight into efficacy of sequenced VEGFR - TKIs and cross - resistance in metastatic renal cell carcinoma.

\section{Conclusion}

Objective responses and stable disease is observed with post-axitinib targeted therapy, although efficacy is generally less than that seen with axitinib. Prospective studies will help us understand if prior response or resistance to axitinib predicts for clinical benefit to subsequent therapy. Variable patient response to drugs in the same class warrants prospective studies to validate role of predictive biomarkers in guiding individualized therapies and improving outcomes.

\section{Ethics approval and consent to participate}

Waived.

\section{Consent for publication \\ Non-applicable.}

\section{Availability of data and materials}

The dataset supporting the conclusions of this article is available at request from the corresponding author.

\section{Abbreviations}

MI: Myocardial Infarction; mRCC: metastatic renal cell carcinoma; ORR: overall response rate; OS: overall survival; PDGF: platelet derived growth factor; PFS: progression free survival; RCC: renal cell carcinoma; RECIST: response evaluation criteria in solid tumors; RPLS: Reversible Posterior Leukoencephalopathy Syndrome; VEGF: vascular endothelial growth factor; VHL: von Hippel-Lindau.

\section{Competing interests}

EJ has received research funding from and acted as consultants for Pfizer, GlaxoSmithKline and Novartis. BR has received research funding from Pfizer and acted as consultant for Pfizer. NT has received research funding from and served on advisory board for Pfizer. LW has received honoraria from Pfizer. RD has acted as a consultant for Novartis. JG has received research funding from Pfizer, Novartis and Astellas and served on advisory board for Pfizer, GSK, Astellas and Aveo. NC, HH and PE have no conflicts of interest.

\section{Authors' contributions}

NC made substantial contribution to acquisition, analysis and interpretation of data, drafting and submission of the manuscript. HH contributed to design of the study, acquisition of the data and drafting of the manuscript. PE contributed to the design of the study and performed the statistical analysis. BR conceived the study, participated in its design and coordination and contributed to interpretation of the data and drafting of the manuscript. $E J, N T, L W, R D, J G$ participated in the design of the study, contributed to the interpretation of the data and drafting of the manuscript. All authors read and approved the final manuscript.

\section{Acknowledgements}

None.

\section{Funding}

This study was conducted without any specific source of funding.

\section{Author details}

${ }^{1}$ Cleveland Clinic Taussig Cancer Center, 9500 Euclid Ave., Cleveland, OH, USA. ${ }^{2}$ University of Texas M. D. Anderson Cancer Center, Houston, TX, USA. ${ }^{3}$ University of Virginia, 1240 Lee St., Charlottesville, VA, USA. ${ }^{4}$ Veteran Affairs Medical Center, 800 Irving Avenue, Syracuse, NY 13210, USA.

Received: 18 June 2015 Accepted: 15 March 2016

Published online: 29 March 2016

\section{References}

1. Linehan WM, Srinivasan R, Schmidt LS. The genetic basis of kidney cancer: a metabolic disease. Nat Rev Urol. 2010;7(5):277-85.

2. Escudier B, Pluzanska A, Koralewski P, Ravaud A, Bracarda S, Szczylik C, Chevreau, M. Filipek, B. Melichar, E. Bajetta, V. Gorbunova, J.O. Bay, I. Bodrogi, A Jagiello-Gruszfeld, and N. Moore. Bevacizumab plus interferon alfa-2a for treatment of metastatic renal cell carcinoma: a randomised, double-blind phase III trial. Lancet. 2007;370(9605):2103-11.

3. Escudier B, Eisen T, Stadler WM, Szczylik C, Oudard S, Siebels M, Negrier, C. Chevreau, E. Solska, A.A. Desai, F. Rolland, T. Demkow, T.E. Hutson, M. Gore, S. Freeman, B. Schwartz, M. Shan, R. Simantov, and R.M. Bukowski. Sorafenib in advanced clear-cell renal-cell carcinoma. N Engl J Med. 2007;356(2):125-34.

4. Motzer RJ, Hutson TE, Tomczak P, Michaelson MD, Bukowski RM, Rixe O, S. Oudard, S. Negrier, C. Szczylik, S.T. Kim, I. Chen, P.W. Bycott, C.M. Baum, and R.A. Figlin. Sunitinib versus interferon alfa in metastatic renal-cell carcinoma. N Engl J Med. 2007;356(2):115-24.

5. Rini BI, Halabi S, Rosenberg JE, Stadler WM, Vaena DA, Archer L, J.N. Atkins, J. Picus, P. Czaykowski, J. Dutcher, and E.J. Small. Phase III trial of bevacizumab plus interferon alfa versus interferon alfa monotherapy in patients with metastatic renal cell carcinoma: final results of CALGB 90206. J Clin Oncol. 2010;28(13):2137-43.

6. Sternberg CN, Davis ID, Mardiak J, Szczylik C, Lee E, Wagstaff J, C.H. Barrios, P. Salman, O.A. Gladkov, A. Kavina, J.J. Zarba, M. Chen, L. McCann, L. Pandite, D.F. Roychowdhury, and R.E. Hawkins. Pazopanib in locally advanced or metastatic renal cell carcinoma: results of a randomized phase III trial. J Clin Oncol. 2010; 28(6):1061-8.

7. Rini Bl, Escudier B, Tomczak P, Kaprin A, Szczylik C, Hutson TE, M.D. Michaelson, V.A. Gorbunova, M.E. Gore, I.G. Rusakov, S. Negrier, Y.C. Ou, D. Castellano, H.Y. Lim, H. Uemura, J. Tarazi, D. Cella, C. Chen, B. Rosbrook, S. Kim, and R.J. Motzer. Comparative effectiveness of axitinib versus sorafenib in advanced renal cell carcinoma (AXIS): a randomised phase 3 trial. Lancet. 2011;378(9807):1931-9. 
8. Hanahan D, Weinberg RA. Hallmarks of cancer: the next generation. Cell. 201 1;144(5):646-74.

9. Hudes G, Carducci M, Tomczak P, Dutcher J, Figlin R, Kapoor A, E. Staroslawska, J. Sosman, D. McDermott, I. Bodrogi, Z. Kovacevic, V. Lesovoy, I.G. Schmidt-Wolf, O. Barbarash, E. Gokmen, T. O'Toole, S. Lustgarten, L. Moore, and R.J. Motzer. Temsirolimus, interferon alfa, or both for advanced renal-cell carcinoma. N Engl J Med. 2007;356(22):2271-81.

10. Motzer RJ, Escudier B, Oudard S, Hutson TE, Porta C, Bracarda S, V. Grunwald, J.A. Thompson, R.A. Figlin, N. Hollaender, A. Kay, and A. Ravaud. Phase 3 trial of everolimus for metastatic renal cell carcinoma: final results and analysis of prognostic factors. Cancer. 2010;1 16(18):4256-65.

11. Calvo E, Ravaud A, Bellmunt J. What is the optimal therapy for patients with metastatic renal cell carcinoma who progress on an initial VEGFr-TKI? Cancer Treat Rev. 2013;39(4):366-74.

12. Bex A, Haanen J. Tilting the AXIS towards therapeutic limits in renal cancer. Lancet. 2011;378(9807):1898-900.

13. Heng DY, Xie W, Regan MM, Warren MA, Golshayan AR, Sahi C, B.J. Eigl, J.D. Ruether, T. Cheng, S. North, P. Venner, J.J. Knox, K.N. Chi, C. Kollmannsberger, D. F. McDermott, W.K. Oh, M.B. Atkins, R.M. Bukowski, B.I. Rini, and T.K. Choueiri. Prognostic factors for overall survival in patients with metastatic renal cell carcinoma treated with vascular endothelial growth factor-targeted agents: results from a large, multicenter study. J Clin Oncol. 2009;27(34):5794-9.

14. Dudek AZ, Zolnierek J, Dham A, Lindgren BR, Szczylik C. Sequential therapy with sorafenib and sunitinib in renal cell carcinoma. Cancer. 2009;115(1):61-7.

15. Sablin MP, Negrier S, Ravaud A, Oudard S, Balleyquier C, Gautier J, Celier J. Medioni and B. Escudier. Sequential sorafenib and sunitinib for renal cell carcinoma. J Urol. 2009;182(1):29-34. discussion 34.

16. Escudier B. Signaling inhibitors in metastatic renal cell carcinoma. Cancer J. 2008:14(5):325-9.

17. Tamaskar I, Garcia JA, Elson P, Wood L, Mekhail T, Dreicer R, B.I. Rini, and R. $M$. Bukowski. Antitumor effects of sunitinib or sorafenib in patients with metastatic renal cell carcinoma who received prior antiangiogenic therapy. J Urol. 2008;179(1):81-6. discussion 86.

\section{Submit your next manuscript to BioMed Central and we will help you at every step:}

- We accept pre-submission inquiries

- Our selector tool helps you to find the most relevant journal

- We provide round the clock customer support

- Convenient online submission

- Thorough peer review

- Inclusion in PubMed and all major indexing services

- Maximum visibility for your research

Submit your manuscript at www.biomedcentral.com/submit

) Biomed Central 